\title{
Parliaments, constitutional conventions, and popular sovereignty
}

\begin{abstract}
There is growing interest in the UK in holding a constitutional convention (CC) to deliberate possible reforms to the political system. What form should a $\mathrm{CC}$ take? Having identified a range of possible models, we examine their merits according to stated normative criteria focusing specifically on: (a) how CC membership is determined; (b) whether a CC should have agenda-setting power; and (c) whether it should have power to send proposals to binding referendum. We find good reasons to support a 'citizen majority' membership (chosen in a near-random fashion from the general public); agenda-setting-power; and referendum power. However, none of these features is likely to be the most appropriate in all contexts. Further design issues concerning citizen-majority conventions, such as whether they ought to include politicians as a minority or exclude them, are also considered. While the immediate focus of discussion is the UK, the core argument has wider relevance.
\end{abstract}

Keywords Constitutional convention, parliament, popular sovereignty, democracy, UK politics.

\section{Introduction}

A constitutional convention (CC) is a body charged with deliberating and proposing a draft constitution or constitutional amendment(s), typically subject to ratification through a wider political process. ${ }^{1}$ Recently, there has been interest in a constitutional convention process to deliberate the future of the UK's political system. Although the current UK government is not supportive of the idea, it may find traction in years to come. What form, however, should a CC take? How should it be structured?

Discussion of a CC in the UK has been influenced by recent examples of assemblies in which members of the general public have been directly involved in deliberating proposals for political reform. These include: two citizens' assemblies in Canada that examined 
electoral reform (British Columbia in 2004, Ontario in 2006/7); the Burgerforum on electoral reform in the Netherlands (2006); the Icelandic constitution drafting process of 2010-12; and the recent constitutional convention in Ireland, 2013/14. ${ }^{2}$ In all these cases, the relevant assembly/convention was established by the existing parliament. One particularly important aspect of the general design question about $\mathrm{CCs}$, and the main focus of this paper, is: How should powers and responsibilities be divided as between CCs and parliaments? Although our immediate focus is the UK, our discussion has wider relevance.

We proceed as follows. First, in section 1, following a brief review of the emerging $\mathrm{CC}$ discussion in the UK, I outline three key design questions and several $\mathrm{CC}$ models based on different answers to them. Section 2 then outlines some normative criteria to use to assess these options. These criteria relate to: epistemic value (how good the institution is at selecting good outcomes); popular sovereignty (which relates to the values of political autonomy, inclusive responsibility, civic equality); and avoidance of 'majority tyranny'. In sections 3-5, I apply the criteria to the three key design questions: membership of the $\mathrm{CC}$; whether it should have agenda-setting power; and whether it should be empowered to send recommendations to binding referendum. I argue that, while it is difficult to make any absolute recommendations, there are good reasons for CCs to have a 'citizen-majority' (a membership the majority of whom are members of the general public, preferably chosen on a near-random basis to be descriptively representative); agenda-setting power; and referendum power. In section 6 I consider a further set of design questions to refine our grasp of citizenmajority conventions and clarify some points of reasonable disagreement about their structure. Section 7 concludes with a summary and comment on how our analysis, by clarifying the kinds of $\mathrm{CC}$ favoured in principle, itself serves the value of popular sovereignty.

\section{Different models of a constitutional convention}


Interest in a $\mathrm{CC}$ has emerged in the $\mathrm{UK}$ as a way of addressing reform of the political system, particularly the territorial division of powers across the UK and the lack of a codified constitution. The Brown government's interest in constitutional reform was one stimulus (Blick 2015, 215-218). First Minister of Wales, Carwyn Jones AM, argued in 2012 for a Convention on the Future of the UK (Jones 2012). The House of Commons Political and Constitutional Reform Committee, chaired by Labour MP Graham Allen, published on the topic in 2013 (House of Commons 2013). In the run up to Scotland's 2014 independence referendum, discussion intensified (Renwick 2014). Immediately after the referendum, the Electoral Reform Society (ERS) and Unlock Democracy initiated online petitions for a CC that together received over 15,000 signatures. ${ }^{3}$ Political parties, including Labour, the Liberal Democrats, UKIP, and the Greens, also called for a CC (Labour Party 2014). One outcome of discussions was a statement in the March 2015 legacy paper of the All-Party Parliamentary Group (APPG) on Reform, Decentralisation and Devolution in the United Kingdom that called on the parties to include a commitment to a $\mathrm{CC}$ in their manifestos (Purvis and Blick $2015,7)$.

The 2015 general election produced a Conservative government that is unlikely to call a CC. Nevertheless, interest remains. The ERS cooperated with academics to hold two pilot citizens' assemblies in Southampton and Sheffield in October and November 2015 to consider the future of local government in England. ${ }^{4}$ The assemblies were intended to provide evidence for designing a CC with a wider remit (Flinders et al 2016). Liberal Democrat peer, Lord Purvis of Tweed, presented a Constitutional Convention Bill in the House of Lords in 2015, supported by Allen in the Commons (Mortimer 2015). The CC proposal in the Purvis Bill is similar to the proposal of the aforementioned APPG report. ${ }^{5}$ Allen announced in a Commons debate in July 2016 a plan for a possible 'convention' to be launched on a cross-party basis from Opposition with support from a charitable foundation. ${ }^{6}$ 
Campaigns such as Occupy Democracy and Assemblies for Democracy have also promoted a $\mathrm{CC}^{7}$

Interest in a CC, however, is consistent with very different conceptions of a CC. An important contribution to UK discussion is Alan Renwick's After the Referendum which helpfully distinguishes three key sets of design questions: ${ }^{8}(1)$ membership of the convention (membership questions); (2) agenda and the allocation of agenda-setting power (agenda questions); and (3) procedure for deciding what happens to the convention's recommendations (output questions). ${ }^{9}$

The first question set concerns the basis on which $\mathrm{CC}$ members are chosen. One possibility, for example, is to choose $\mathrm{CC}$ members at random from the general public but in a way that is 'stratified' so that the $\mathrm{CC}$ is descriptively representative of the population along criteria such as gender, race, and region. Following the example of the citizens' assemblies in British Columbia and Ontario, the selection of members on a near-random basis may be combined with an internal process divided into three phases: a learning phase dedicated to getting to grips with the questions and approaches; a consultation phase in which the participants hear testimony; and a final phase in which they deliberate and produce their own proposals (Flinders et al 2016, 18). Discussion at all stages is professionally facilitated.

The second design question concerns issues the $\mathrm{CC}$ will address and who decides on these issues. For example, in the Purvis Bill, the CC addresses only specific issues given to it by parliament. Alternatively, a CC might have some power to set its agenda. The third question concerns the CC's recommendations. These could go back to parliament, or the CC could have the power to send them directly to binding referendum.

We can thus get a preliminary sense of the possibilities if we distinguish CCs by three criteria: (a) Citizen majority? Are members of the general public, as distinct from those in or close to professional politicians, a majority in the $\mathrm{CC} ?^{10}$ (b) Agenda-setting power? Does the 
CC have significant power to set its agenda independent of parliament? (c) Referendum power? Does the $\mathrm{CC}$ have power to send its recommendations to binding referendum(s)? Table 1 sets out the eight answers to these design questions.

Table 1: Some types of constitutional convention (CC)

\section{Citizen majority? $\quad$ Agenda-setting power? $\quad$ Referendum power?}

$\begin{array}{llcc}\text { CC } 1 & \text { Yes } & \text { Yes } & \text { Yes } \\ \text { CC2 } & \text { Yes } & \text { No } & \text { Yes } \\ \text { CC3 } & \text { Yes } & \text { Yes } & \text { No } \\ \text { CC4 } & \text { Yes } & \text { No } & \text { No } \\ \text { CC5 } & \text { No } & \text { Yes } & \text { Yes } \\ \text { CC6 } & \text { No } & \text { No } & \text { Yes } \\ \text { CC7 } & \text { No } & \text { Yes } & \text { No } \\ \text { CC8 } & \text { No } & \text { No } & \text { No }\end{array}$

To elaborate, $\mathrm{CC} 1$ has members of the general public as a majority, e.g., perhaps selected on a quasi-random basis. It has significant power - relative to parliament - to set its agenda. It has power to send its recommendations to binding referendum. Renwick's proposed CC is a version of CC1 (Renwick 2014, 95-123). CC2 has both a majority of 'citizen conventioners" ${ }^{11}$ and is referendum empowered. But its agenda is given to it wholly by parliament. The citizens' assemblies used in British Columbia and Ontario to deliberate electoral reform proposals are versions of CC2.

CC3 has a citizen majority and agenda-setting power. However, it lacks referendum power. The recent Irish constitutional convention has some similarity with CC3: a clear citizen majority, a degree of agenda-setting power, but no referendum power. CC4 has a 
citizen majority but no agenda-setting or referendum power. Thus, it can only advise parliament on specific issues defined by parliament. The Dutch Burgerforum is a case of CC4 (tasked by the Dutch parliament to develop an electoral reform proposal). ${ }^{12}$ The Irish convention was close to $\mathrm{CC} 4$ because, as well as not being referendum powered, its agendasetting power was very limited. ${ }^{13} \mathrm{CC} 4$ is consistent with the $\mathrm{CC}$ proposed in the Purvis Bill. ${ }^{14}$

Models CC5-CC8 don't have a citizen majority. The CC may consist, for example, of professional politicians and representatives of major civil society groups (e.g., faith groups, business organizations, trade unions), with members of the general public in a minority or not present at all. Models CC5-CC8 then differ according to whether the $\mathrm{CC}$ has agenda-setting and/or referendum powers. In the case of $\mathrm{CC} 8$, for example, we have a $\mathrm{CC}$ that might consist primarily of professional politicians and civil society group representatives; has an agenda defined by parliament; and sends recommendations to parliament. The proposal set out in the Purvis Bill, while consistent with CC4, can also be read as a form of CC8. ${ }^{15}$

\section{Assessment criteria}

We have seen that interest in a CC is consistent with very different conceptions of a CC. Looking at just two recent UK proposals (those of Renwick and Purvis), we see possibilities ranging from $\mathrm{CC} 1$ to $\mathrm{CC} 4$ and $\mathrm{CC} 8$. Are some models more desirable than others? To answer the question we need some criteria to guide our assessment. Building on Renwick's discussion, I now set out some criteria (Renwick 2014, 95-103).

(1) Epistemic value.

The epistemic value of a political process concerns how well it selects good policies. Epistemic value is related to the concerns that Renwick highlights for impartiality and deliberative quality (Renwick 2014, 95-96). Impartiality means that a CC elevates 'reason' over 'interest' and 'passions'. ${ }^{16}$ Deliberative quality means that decisions are 'based on solid understanding of the options and of the implications that adopting each of those options 
would have' (Renwick 2014, 96). A CC model is better, the more epistemic value it has, where epistemic value is served by impartiality and deliberative quality.

As Renwick notes, aside from epistemic value, there is something inherently valuable about the people making the fundamental laws that define their political system (Renwick $2014,97)$. We can relate this value of popular sovereignty to three other values: political autonomy; inclusive responsibility; and civic equality.

(2) Political autonomy.

In Rousseau's influential formulation, a legitimate state is one in which the people give to themselves the laws they must follow (Rousseau 1994). Without wholly endorsing Rousseau's theory, his discussion captures one important intuition about freedom. A free individual in a political community has political autonomy: the opportunity to participate, as an equal, and as a free, imaginative agent, in making the laws of the political community, including its most basic, constitutional laws.

(3) Inclusive responsibility.

Popular sovereignty expresses not just an idea of autonomy but of inclusive responsibility: we all have a responsibility for the fundamental well-being of the society and, hence, to participate in shaping its basic laws.

(4) Civic equality.

The right and responsibility of each individual to participate in shaping the basic laws of their polity also expresses the value of civic equality, that all have equal civic standing.

(5) Preventing majority tyranny.

A further criterion is that of preventing 'majority tyranny', a 'majoritarianism' that threatens rights and equality. The concern to prevent majoritarianism is related to the value of impartiality noted above. It is also related to popular sovereignty values such as political autonomy and civic equality (as majoritarianism could infringe these values). 
Let us now consider what these criteria imply when applied in turn to the three design questions. $^{17}$

\section{Should a CC have a citizen majority?}

A CC has a 'citizen majority' when a majority of its members are from the general public rather than professional politicians or representatives of civil society groups. Representatives of civil society groups (e.g. faith leaders) might often be socially close to professional politicians and may thus share their perspective to a significant degree. The intuitive idea of a citizen-majority $\mathrm{CC}$, therefore, is that of a $\mathrm{CC}$ that has a majority of its membership drawn from outside the ranks of professional politicians and/or those socially close to them.

Let us consider what can be said for the citizen-majority feature. There is, firstly, an epistemic argument rooted in the concern for impartiality. CCs typically focus on design of the political system. Politicians have a strong incentive to bias deliberations on the political system to favour their interests (Thompson 2008). ${ }^{18}$ However, the danger of politicians shaping $\mathrm{CC}$ discussion to serve their interests is significantly reduced if $\mathrm{CC}$ membership comes mainly from the general public rather than from the politicians or those socially close to them. Secondly, and remaining with epistemic considerations, descriptive representation in the CC enhances cognitive diversity and so promotes deliberative quality (Landemore 2015, 176-179). The deliberative benefit of descriptive representation gives further support to the citizen-majority principle, at least if the principle is implemented in a way that achieves a high degree of descriptive representation.

What about popular sovereignty values? Imagine a $\mathrm{CC}$ consisting, to at least a majority, of citizens chosen on a near random basis to be descriptively representative. By assembling a near-random cross-section of the general public to deliberate, the $\mathrm{CC}$ is, at least to a majority, a microcosm of 'We the people'. Descriptive representation thereby affirms 
symbolically that responsibility for the constitution is not primarily a matter for elites or experts but of everyone, and thereby also expresses and supports the underlying ideas of inclusive responsibility and civic equality. ${ }^{19}$ Additionally, the descriptive representativeness of the convention might help the citizen trust in the assembly's recommendations and so better identify with its recommendations, narrowing the gap between the perspective of the individual and the law - a gain for political autonomy (Cutler et al 2008).

It is perhaps worth noting explicitly one kind of case which strikingly brings together the epistemic and popular sovereignty concerns. In the UK and the USA some argue that business corporations and rich individuals currently can unduly influence policy by means of such things as campaign contributions and offers of post-office employment to parliamentarians (Wilks-Heeg, Blick and Crone 2012, Lessig 2015). In the US context, Lawrence Lessig argues that the problem is very hard to solve from within normal legislative politics precisely because legislators' incentives have been shaped by the problem. One way to tackle it is to have a process to develop and enact proposals for reform independent of the legislature. A constitutional convention process could serve, but, given the claim about legislators' incentives, it is very unlikely to perform the corrective role assigned to it if its membership is drawn mainly from parliament. Impartiality in approaching the problem of 'money in politics', and, relatedly, the defence (or restoration) of political autonomy and civic equality at the level of ordinary legislative politics, is supported by having a citizenmajority CC. Let's call the concern just described, in support of a citizen-majority CC, the anti-oligarchy concern.

What might be said against the citizen-majority feature? Firstly, it might be argued that a more elite-centred $\mathrm{CC}$ will bring greater expertise to discussion, raising deliberative quality. However, on any constitutional issue on which politicians have a conflict of interest e.g., in relation to the design of the political system, their contribution may be of a high 
quality, but as already explained, it can be expected to compromise impartiality. Moreover, it is entirely consistent with the idea of a citizen-majority $\mathrm{CC}$ that politicians, academic experts and others can be included as a minority; or, if not included as members, as witnesses, enabling their expertise to be tapped (Renwick 2014, 108-109). Thus, the first argument is unconvincing.

A second argument, however, is that a more elite-centred CC could actually improve impartiality by countering possible pressures towards majoritarianism in a $\mathrm{CC}$ setting. However, as already noted, politicians and experts can give input even if they do not constitute a majority of $\mathrm{CC}$ members. In addition, it is possible to design the $\mathrm{CC}$ itself in ways that work to counter majoritarian pressures. The basic division of the CC's work into learning, testimony and deliberation phases, supported by professional facilitation, fosters impartiality. Moreover, majoritarianism may be better countered by ensuring strong representation of people from minority groups themselves in the $\mathrm{CC}$ than by having a majority of professional politicians, not least because the politicians may themselves be exposed to majoritarian pressures. Minority representation is promoted by descriptive representation in the context of a citizen-majority $\mathrm{CC}$; or, even more so, by aiming in membership at a statistical overrepresentation of minority groups in the context of a citizenmajority CC. On the other hand, Renwick points out that in contexts (such as Northern Ireland) where 'constitution-making is widely seen as a negotiation between groups', each 'side' may feel confidence in the process only if represented by the 'strongest possible negotiators' (Renwick 2014, 101). There is then a compelling argument against the citizenmajority model.

Thirdly, a critic might emphasise the possible gap between the ideal of descriptive representation and the reality of a $\mathrm{CC}$. In practice, many may refuse to serve on a $\mathrm{CC}$ if called. As a result, the CC will get skewed towards those with more interest in political 
issues, compromising its descriptive representativeness. ${ }^{20}$ The critic might claim that, in such a situation, the $\mathrm{CC}$ will be seen as less legitimate than the elected legislature. ${ }^{21}$ By extension, citizens may have more confidence in a $\mathrm{CC}$ that takes its majority from the legislature.

There are a number of responses to the above argument. While achieving descriptive representation is a challenge, assemblies chosen in the suggested manner (stratified random selection) are typically more representative in some respects, such as gender, than elected bodies. Thus, if descriptive representativeness matters to perceived legitimacy, it is not clear why the general public should see them as less legitimate, and have less trust in them, than elected legislatures. Evidence from British Columbia, for example, indicates that citizens who knew of the work of the citizens' assembly put a degree of trust in its recommendations in part because of its descriptively representative nature (Cutler et al 2008, Warren and Pearse 2008b). Second, while achieving descriptive representation is hard, it may be achievable to a high degree if the resources are put into the task. ${ }^{22}$ Third, even if we accept the thrust of the above argument, the implication is not necessarily that we should draw the bulk of a CC's membership from parliament (and/or socially proximate civil society representatives). We might elect the $\mathrm{CC}$ itself. Doing so remains at least roughly compatible with the idea of a citizen-majority $\mathrm{CC}$ if we restrict candidacy for the majority of the $\mathrm{CC}$ 's places to non-politicians.

On balance, then, the case for a citizen-majority $\mathrm{CC}$ is strong, though majoritarianism concerns might tell against it in some contexts. We will return to some of the issues raised in this section's discussion in section 6.

\section{Should a CC have agenda-setting power?}

Let us now turn to the second design issue: whether the CC should have independent (of parliament) agenda-setting power. 
There are strong epistemic and popular sovereignty arguments in favour of the CC having agenda-setting power. Recall the worry about politicians' conflict of interest on some constitutional issues, notably those related to the design of the political system. If parliament wholly sets the CC's agenda, MPs can keep off the table options that do not serve their interests, compromising impartiality. Also, if the $\mathrm{CC}$ has agenda-setting power, members of the public can campaign to it to address their concerns. The $\mathrm{CC}$ can then become the focus of a wider public conversation about constitutional problems and can respond to this conversation. The wider conversation, and $\mathrm{CC}$ responsiveness to it, enhances political autonomy and also, in itself, better expresses and promotes inclusive responsibility and civic equality. Agenda-setting power thereby serves popular sovereignty values. What I referred to above as the anti-oligarchy concern, when applicable, also supports the case for the CC having agenda-setting power.

Are there strong arguments against agenda-setting power? A first argument points to deliberative risks from failing to set the CC's agenda. We know that citizens' assemblies selected on a near-random basis deliberate well on specific topics, e.g., electoral reform. But what if a CC is not given a specific topic? Will the CC's discussion lack focus and depth? We have no example of a citizens' assembly successfully engaging with a completely open or very broad remit (Smith 2009, 281-282). Thus it might seem advisable to let parliament identify topics for consideration. Although there is some loss in political autonomy, arguably the gain in epistemic terms is worth it.

The above argument fails to distinguish, however, between the scope and independence of the CC's agenda. Accept for the moment the need for the $\mathrm{CC}$ to address a limited number of specific topics. It does not follow that these must all be externally defined. A CC can choose topics for consideration, and so exercise agenda-setting power, even if some topics are given to it externally and there is a limit to the number of topics it can 
consider. If limited scope in the agenda is necessary for deliberative quality, limited scope is compatible with independent agenda-setting power. ${ }^{23}$

Is the notion of a 'topic' too vague, however? What if a $\mathrm{CC}$ decided to address the entirety of the constitution under its agenda-setting power, citing the whole constitution or political system as 'a topic'? One possible response is for legislation establishing the CC to include clear, illustrative guidance on the scope of a 'topic'. ${ }^{24}$ More straightforwardly legislation can specify a length of time in which further 'topics' may be considered and leave it to the $\mathrm{CC}$ to work out what it can realistically achieve in the available time. The Irish convention was given such an opportunity (though the length of time allowed was rather limited). It is possible the $\mathrm{CC}$ will take on too much, but members have an incentive to be realistic. If they are not, they have less chance of effecting any change.

Another objection is that allowing agenda-setting power to a $\mathrm{CC}$ may make it easier for majoritarianism to shape the CC's agenda and eventually shape the law. The worry increases if the $\mathrm{CC}$ also has referendum power (discussed further below). There is then the possibility of the $\mathrm{CC}$ responding to majoritarian demands by putting a proposal to discussion and then referendum with no opportunity for parliament or another external body to intervene. Recall that values linked to popular sovereignty, such as civic equality and political autonomy, might be threatened by majoritarianism. So there is not only a risk of loss in epistemic terms, but of loss to these values too.

As noted above, if well-designed and well-run, the $\mathrm{CC}$ itself acts as a filter against majoritarianism. In principle we can strengthen the filter, if we want, such as by requiring that any referendum proposal get the approval of multiple CC-type assemblies (Zurn 2007). ${ }^{25}$ We can also stipulate supermajority and other thresholds as conditions for success at the referendum stage. Still, one might ask: Why not use parliament as a complementary filter, 
e.g., at the agenda-setting point? Doing so might be effective and more practical than, say, requiring multiple CC-type assemblies.

For issues concerning political structure where parliamentarians have a conflict of interest there is, for reasons set out above, a strong presumption against using parliament as a filter. However, not all constitutional issues generate such a conflict. For example, an issue concerning the scope of religious liberty may present no conflict of interest to politicians as such. But the same issue might also carry a high risk of majoritarianism. Giving parliament the power to set fully the CC's agenda might then help counter the majoritarian risk. Much rests, however, on how far parliamentarians are themselves likely to be sensitive to majoritarian pressures. Note also that even in such a case, we don't necessarily have to deny the CC all agenda-setting power. It might be possible for parliament to stipulate that certain issues are on the CC's agenda and that certain issues cannot be put on its agenda. Such a stipulation still leaves space for some agenda-setting power.

Overall there is a case for allowing a $\mathrm{CC}$ agenda-setting power, though epistemic and majoritarian concerns call for care. It seems especially important for the $\mathrm{CC}$ to have agendasetting power in relation to issues about political structure on which politicians have a conflict of interest.

\section{Should a CC have referendum power?}

Let's now turn to the third design question: whether the $\mathrm{CC}$ should have power to send recommendations to binding referendum.

Where a constitutional issue presents politicians with a conflict of interest, impartiality is served by giving the $\mathrm{CC}$ referendum power as doing so prevents politicians selfishly shelving proposals. ${ }^{26}$ By depriving politicians of opportunity to shelve proposals, the referendum power also serves political autonomy. It also expresses and promotes inclusive responsibility and civic equality. To be precise, it is partly that the referendum power 
expresses and promotes these values by affirming that such power, to call a binding referendum, can properly lie with those who are not professional politicians (with 'people like me'). In addition, the referendum power expresses and promotes these values because binding referendums themselves express and promote these values. The anti-oligarchy concern noted above, when applicable, also supports the case for referendum power.

One objection to the referendum power, as we have seen, is that it may facilitate majoritarianism. Where there is risk of majoritarianism, should parliament hold a veto power on whether a CC's recommendation goes to binding referendum? Again, we can point to ways in which the risk of majoritarianism can be limited without eliminating the referendum power, such as setting supermajority thresholds as conditions of referendum success. There is also, once again, the point that it seems ill-advised to give parliament such a power on issues where politicians have a conflict of interest. Nevertheless, it seems too sweeping to reject the parliamentary veto as unreasonable in all circumstances.

A more radical position is that we should dispense with referendums altogether, and give parliament alone the final say on a CC's recommendations. Even if discussion within the $\mathrm{CC}$ is of high quality, there might be a 'deliberative gap' between the $\mathrm{CC}$ and subsequent referendum. Referendums can exhibit low deliberative quality (Bell Jr. 1978, Chambers 2001, Smith 2009, 360-383, Blick 2015, 256). As a result, and even if majority tyranny is not at stake, excellent proposals may fall at the referendum stage, undoing the CC's work (the electoral reform proposals developed by the British Columbia and Ontario citizens' assemblies failed at referendum). Perhaps, then, parliament should vote on the CC's proposals rather than putting them to referendum?

In general, removing the need for a referendum on constitutional issues - even one agreed to by both CC and parliament - comes at a high cost to popular sovereignty values. It takes fundamental decisions on the constitutional order away from direct and authoritative 
judgment by 'We the people'. In addition, there might be ways of addressing the possible deliberative gap between the $\mathrm{CC}$ and referendum. Efforts to involve a wider public in the CC's discussion, through the 'crowdsourcing' of responses and proposals, as in the case of the recent Icelandic CC, can possibly help to stimulate engagement ahead of a referendum (Landemore 2015). ${ }^{27}$

Let us now draw the threads of sections 3-5 together. Doing so is not easy as there are multiple considerations pointing in different directions. But to hazard a summary we can say, firstly, that there are strong reasons for respectively favouring citizen-majority, agendasetting and referendum powers in a $\mathrm{CC}$. Taken together, these reasons thus indicate $\mathrm{CC} 1$ as a preferred model for a constitutional convention. However, some departures from CC1 will likely be justified in some contexts, as responses to epistemic and/or majoritarianism concerns. A reasonable rule to adopt is: Take CC1 as the baseline for design, in view of its epistemic benefits and fit with popular sovereignty values; but be careful to test CC1, in context, against the assessment criteria, notably epistemic and majoritarianism concerns. ${ }^{28}$

\section{Elaborating the citizen-majority convention}

This section considers further design questions that arise in elaborating a citizenmajority $\mathrm{CC}(\mathrm{CC} 1, \mathrm{CC} 2, \mathrm{CC} 3$ and $\mathrm{CC} 4)$.

\subsection{Citizen-majority or citizen-only?}

The category of 'citizen majority' is consistent with a citizen-only CC or one that has a simple citizen majority. Why not go for a citizen-only CC?

As noted earlier, one might argue that the presence of a minority of politicians (and perhaps experts and/or civil society representatives) will raise deliberative quality, offering valuable insight without risk of their dominating the conversation. Perhaps their presence might also help counter majoritarianism, though such an effect is very dependent on the pressures faced by the politicians. There is also an important pragmatic, 'buy in' argument 
that politicians should be included in a $\mathrm{CC}$ as a minority as their presence will foster acceptance of proposals by the current political elite and so increase the likelihood of the proposals being enacted (Renwick 2014, 101-103, 118-119, Blick 2015, 251).

One worry about including politicians, even as a minority, is that they might still dominate discussion with costs both epistemically and to popular sovereignty values. The 'Democracy Matters' pilot assemblies tested specifically for the domination effect by comparing a citizen-only assembly (Assembly North, Sheffield) with a citizen-majority assembly that included a minority of local councilors (Assembly South, Southampton). The politicians' presence had a negative effect on deliberation initially. Although the difference between the two assemblies diminished between the first and second set of meetings, the reasons are not clear, and might reflect that there just were fewer politicians present at Assembly South's second meeting (Flinders et al 2016, 14, 38-40). Thus, the study does not altogether dispel the concern about politicians' presence being detrimental to deliberative quality.

Further, it might be objected that the 'buy in' argument for including politicians necessarily assumes a compromise with epistemic value and popular sovereignty values. If their inclusion makes for an outcome they feel more able to support, won't their support be because their presence has skewed the outcome to serve their interests, at the expense of impartiality and genuine popular sovereignty?

There are at least two replies. One is that such a compromise is indeed being suggested, but that compromise is reasonable. Unless the situation is revolutionary, the existing political elite will have powerful resources and pragmatism calls for compromise. A second reply is that 'buy in' does not necessarily reflect a biased skewing of decisionmaking. It might reflect a shift in what the politicians want, or are willing to accept, based on their participation in the convention (as a minority). If so, then there need be no compromise 
with impartiality or popular sovereignty. A final objection, however, is that including politicians as a minority might not in fact produce much greater 'buy in'. In the Irish case politicians made up $1 / 3$ of the CC's membership but, as noted, the parliament has been criticized for not being responsive to the convention's proposals.

What about including civil society representatives and/or academic experts in the context of a citizen majority? Again, we should note that citizen-majority conventions, including citizen-only versions, are far from 'excluding' experts. They can and should feature as witnesses, giving evidence and argument to the convention (Renwick 2014, 108-109). Civil society representatives can also input their views as witnesses. At the same time, as Renwick argues, including civil society representatives raises the question of which civil society groups will get representation, e.g., which faith groups (Renwick 2014, 56-57). The inevitable exclusion of some groups violates civic equality.

I conclude that there is a reasonable case for a citizen-majority $\mathrm{CC}$ with minority membership of politicians (and/or civil society representatives and/or experts), but that, on the evidence to date, a citizen-only $\mathrm{CC}$ can also be a reasonable option.

\subsection{Election?}

We have tended to assume that a citizen-majority $\mathrm{CC}$ will have its 'citizen conventioners' selected by near-random selection, stratified to make the convention descriptively representative. But why not elect members? Candidates will presumably stand on manifestos. Election can thus give the public opportunity to shape the assembly's orientation. As such, it apparently enhances political autonomy. If we wish to preserve the principle of citizen-majority we can do so by excluding politicians from the election.

There are epistemic and popular sovereignty considerations against election (see also Renwick 2014, 112-114). Although a CC's membership might be somewhat skewed towards those more interested in political issues (see section 5.3), it will likely be a more descriptively 
representative body than one that is elected (for relevant discussion of the Icelandic case, see Landemore 2015, 178-179). A loss of descriptive representation, however, risks a loss of cognitive diversity, a cost in epistemic terms. It also means the convention is not so much a microcosm of 'We the people' and so is less expressive and promotive of inclusive responsibility and civic equality. It is also possible that election might give more momentum to majoritarianism.

Moreover, there are ways other than election by which the wider public can influence the convention's agenda. If the convention has agenda-setting power, it is possible to imagine ways in which the convention takes a lead from the public. So the apparent loss in terms of political autonomy from not using election can be limited (although taking a lead from the public in other ways might reignite the majoritarianism concern). On balance, there seems likely to be a significant epistemic cost and little or no gain in popular sovereignty values from election over stratified, near-random selection. The case tips against election.

\subsection{Like jury duty?}

Should we conceive CC membership as on a par with jury duty, as a civic responsibility that we typically expect people to undertake when called upon ${ }^{29}$ The corollary is that CC members will be paid expenses and compensated for loss of earnings.

The value of inclusive responsibility supports the jury model: everyone shares responsibility for the good of the polity and so, absent difficult personal circumstances, should join a CC when called. Once accepted as legitimate, the jury model will also help tackle the problem of self-selection in $\mathrm{CC}$ recruitment that works against the goal of descriptive representation. It is conceivable also that self-selection may produce a more 'opinionated' assembly of people with strong prior views which obstructs deliberation, though the 'Democracy Matters' pilot assemblies did not find this effect. ${ }^{30}$ 
The main argument in principle against the jury model is that the time and energy commitments of a $\mathrm{CC}$ might be much greater than for juries making the comparison unfair. Concretely, my sense is that membership obligations on the level of the recent Irish convention, which required preparation and attendance for nine weekends over the course of a little over a year, are reasonably seen on the model of jury duty. But the model certainly looks less reasonable if obligations are much heavier than in the Irish convention.

In short, there is a clear civic rationale for thinking of $\mathrm{CC}$ membership on the jury model. However, we must also be sensitive to the time and energy commitment being asked of citizens. If we adopt a more voluntarist approach, then we will need to consider how to address some of the potential drawbacks in terms of descriptive representation. Addressing the drawbacks is likely to require payment above compensation for loss of earnings and so likely raises the cost of the CC.

\section{Conclusion: an analysis that serves popular sovereignty}

There is interest in the UK in a CC to deliberate the future of the UK's political institutions. Proponents do not necessarily agree on the form a CC should take, however. In this paper, I have identified eight basic CC models and set out some criteria to assess them. The arguments and counter-arguments point in different directions, but there is a strong case for a $\mathrm{CC}$ to have a citizen-majority and both agenda-setting and referendum powers $(\mathrm{CC} 1$ in Table 1). The case looks especially compelling in cases where politicians suffer from a conflict of interest regarding a constitutional issue. However, we will always need to test the model in context against the assessment criteria, and we may then find justification for taking up alternatives. I have also tried to shed some further light on the design of CCs with the citizen-majority feature (for example, whether they should include politicians as a minority or be citizen-only). 
In closing I emphasise two things. Firstly, the conclusions I have reached are tentative and provisional. There may be further arguments for or against specific options that I have not anticipated. Also, our evidence base is developing and as it develops new findings may call for revisions to the claims made here. Secondly, we have assumed throughout that the CC is convened by a parliament. In a further discussion, we should relax the assumption. Within the confines of the assumption, however, it might be objected that the results here are unrealistic: in particular, in proposing $\mathrm{CC} 1$ as a desirable option $\mathrm{I}$ am advocating that parliament set up a $\mathrm{CC}$ and in a form that disempowers parliament in relation to the $\mathrm{CC}$. Critics might object that a parliament is unlikely to set up such a CC. I allowed pragmatic concerns to enter above - such as in the 'buy in' argument for including politicians as a minority in the CC. But, critics might say, we should be more pragmatic still. We should only entertain CC proposals that are more aligned with parliamentarians' interests. Consequently, we should exclude CC1 from consideration.

The point, however, is not to rule out or condemn compromises. By giving an analysis that stays close to principle here I am not ruling them out but, rather, helping us to better understand just when and what compromises are indeed being made. I am helping us to be more aware of the distinction between the kinds of $\mathrm{CC}$ favoured in principle and whatever form of $\mathrm{CC}$ might issue from a given political context and its negotiations. A clear appreciation of the distinction is, in itself, somewhat empowering and serves the value of popular sovereignty.

\section{References:}

Bell, Jr., D. A. (1978) 'The Referendum: Democracy’s Barrier to Racial Equality'. Washington Law Review 54, 1-29.

Bergsson, B.T., and Blokker, P., (2014) 'The Constitutional Experiment in Iceland'. In Pocza, K. (ed) Verfassunggebung in konsolidierten Demokratien:

Neubeginn oder Verfall eines Systems? Baden-Baden, Nomos Verlag. 
Blick, A. (2015) Beyond Magna Carta: A Constitution for the United Kingdom. Oxford, Hart.

Caluwaerts, D., and Reuchamps, M. (2016) 'Generating Legitimacy Through Democratic Innovations: The Role of Embeddedness and Disruptiveness', Representation 52, 17-32.

Chambers, S. (2001) 'Constitutional Referendums and Democratic Deliberation'. In Mendelsohn, M. and Parkin, A. (eds.) Referendum Democracy: Citizens, Elites and Deliberation in Referendum Campaigns, Basingstoke, Palgrave, 231-255.

Chawlisz, C. (2015) The Populist Signal: Why Politics and Democracy Need to Change. London, Rowman and Littlefield.

Cutler, F., Johnston R., Carty, K., Blais A, and Fournier P. (2008) 'Deliberation, Information and Trust: The BC Citizens' Assembly as Agenda-Setter'. In Warren, M.E., and Pearse, H. (eds) Designing Deliberative Democracy: The British Columbia Citizens'Assembly. Cambridge, Cambridge University Press, 166-191.

Electoral Reform Society (2015) 'How to do a Constitutional Convention in the UK', http://www.electoralreform.org.uk/sites/default/files/How\%20to\%20do\%20a\%20Convention\%20Mar\%202015.p df

Elster, J. (2012) 'The Optimal Design of a Constituent Assembly'. In Landemore H. and Elster, J. (eds) Collective Wisdom: Principles and Mechanisms. Cambridge, Cambridge University Press, 148-172.

Farrell, D.M. (2014) 'The 2013 Irish Constitutional Convention: A Bold Step or a Damp Squib?'. In Ferrari, G.F., and O'Dowd, J. (eds) 75 Years of the Constitution of Ireland: An Irish-Italian Dialogue. Dublin, Clarus, 292-305.

(2015) 'Constitutional Convention brand is in jeopardy', The Irish Times, 26 March, http://www.irishtimes.com/opinion/david-farrell-constitutional-convention-brand-is-injeopardy-1.2142826

Flinders, M., Ghose, K., Jennings, W., Molloy, E., Prosser, B., Renwick, A., Smith, G., and Spada, P. (2016) Democracy Matters: Lessons from the 2015 Citizens' Assemblies on English Devolution. London, Electoral Reform Society.

Grant, J. (2014) 'Canada's Republican Invention? On the Political Theory and Practice of Citizens’ Assemblies’. Political Studies, 62, 539-555.

House of Commons Political and Constitutional Reform Committee (2013) Do we Need a Constitutional Convention for the UK? London, TSO.

http://www.parliament.uk/documents/commons-committees/political-and-constitutionalreform/CC-Report-FINAL-to-TSO.pdf

Jones. C. (2012) 'Wales and the Future of the United Kingdom', Institute of Welsh Affairs, April 2, http://www.iwa.wales/click/2012/04/wales-and-the-future-of-the-united-kingdom/

Labour Party (2014) 'A Constitutional Convention for the UK; a dynamic new political settlement for England and for Britain', 19 September, 
http://press.labour.org.uk/post/97885913129/a-constitutional-convention-for-the-uk-adynamic

Landemore, H. (2015) 'Inclusive Constitution-Making: the Icelandic Experiment'. Journal of Political Philosophy, 23, 166-191.

Lang, A. (2007) 'But Is It for Real? The British Columbia Citizens' Assembly as a Model of State-Sponsored Citizen Empowerment'. Politics and Society, 35, 35-69.

LeDuc, L. (2011) 'Electoral Reform and Direct Democracy in Canada: When Citizens Become Involved'. West European Politics, 34, 551-567.

Lessig, L. (2015) Republic, Lost:Version 2.0: How Money Corrupts Congress - and a Plan to Stop It, New York, Twelve.

Mortimer, J. (2015), “We need a constitutional convention," says ERS, academics and journalists', Electoral Reform Society, 17 July, http://www.electoral-reform.org.uk/blog/we$\underline{\text { need-constitutional-convention-say-ers-academics-and-journalists }}$

Owen, D. (2014) 'Who are 'the People' in a People's Constitutional Convention?', openDemocracy, 30 September, https://www.opendemocracy.net/ourkingdom/davidowen/who-are-\%E2\%80\%98-people\%E2\%80\%99-in-people\%E2\%80\%99s-constitutionalconvention

Purvis, J., and Blick, A. (2015) A Parliament for Reform 2015-2020: Legacy paper of the AllParty Parliamentary Group on Reform, Decentralisation and Devolution in the United Kingdom. London, Local Government Association, http://www.local.gov.uk/documents/10180/6917361/L1579+APPG+for+reform+Devolution/891e0442-8692-4153-bf35-f12e61207508

Renwick, A. (2014) After the Referendum: Options for a Constitutional Convention. London, The Constitution Society, http://www.consoc.org.uk/wpcontent/uploads/2014/05/J1847_Constitution_Society_Report_Cover_WEB.pdf

Rousseau, J.J., trans. by Betts, C. (1994) The Social Contract. Oxford, Oxford University Press.

Smith, G. (2009) Democratic Innovations: Designing Institutions for Citizen Participation. Cambridge, Cambridge University Press. [References are to the e-book.]

Suteu, S. (2015) 'Constitutional Conventions in the Digital Era: Lessons from Iceland and Ireland'. Boston College International and Comparative Law Review, 38, Article 4, 251-276, http://lawdigitalcommons.bc.edu/iclr/vole38/iss2/4

Thompson, D.F. (2008) 'Who Should Govern Who Governs?' In Warren, M.E., and Pearse, H. (eds) Designing Deliberative Democracy: The British Columbia Citizens'Assembly. Cambridge, Cambridge University Press, 20-50.

Tierney, S. (2012) Constitutional Referendums: The Theory and Practice of Republican Deliberation. Oxford, Oxford University Press. 
Warren, M.E., and Pearse, H. (eds) (2008a) Designing Deliberative Democracy: The British Columbia Citizens'Assembly. Cambridge, Cambridge University Press.

-----, (2008b) 'Introduction: democratic renewal and deliberative democracy.' In Warren, M.E., and Pearse, H. (eds) Designing Deliberative Democracy: The British Columbia Citizens'Assembly. Cambridge, Cambridge University Press, 1-19.

Wilks-Heeg, S., Blick, A., and Crone, S. (2012) How Democratic is the UK? The 2012 Audit, Liverpool, Democratic Audit, http://democracyuk-2012.democraticaudit.com/

Zurn, C. (2007) Deliberative Democracy and the Institutions of Judicial Review, Cambridge, Cambridge University Press.

\section{Notes:}

${ }^{1}$ I thank Anthony Barnett, Elizabeth Greenhalgh, Sudhir Hazareesingh, Olly Huitson, Meira Levinson, Sanford Levinson, Aileen McHarg, John P. McCormick, Karma Nabulsi, David Owen, Scot Peterson, Adam Ramsay, Ben Saunders and two anonymous referees for helpful comments and discussion in writing this paper. Any remaining errors are my own.

2 On British Columbia, see Lang 2007, Warren and Pearse eds. 2008, Smith 2009, Tierney 2012; on Ontario, see LeDuc 2011; the Dutch assembly is discussed in Caluwaerts and Reuchamps 2016; on Iceland, see Bergsson and Blokker 2014, Landemore 2015, Suteu 2015; on Ireland, see Farrell 2014, Suteu 2015; for general overviews, see Renwick 2014, Chawlisz 2015. Tierney 2012 also discusses the Australian People's Constitutional Convention (1999).

3 See Electoral Reform Society, http://www.electoral-reform.org.uk/constitutionalconvention/

${ }^{4}$ See http://citizensassembly.co.uk/

${ }^{5}$ The Bill sets out a range of issues for the $\mathrm{CC}$ to consider, such as 'devolution of legislative and fiscal competence to and within Scotland, England, Wales and Northern Ireland' and 'reform of the electoral system'. It envisages that recommendations go back to Parliament for consideration. On membership, it requires representation from 'registered political parties', 'local authorities', 'nations and regions' of the UK, and that '[a]t least 50\% of the members of the convention must not be employed in a role which can reasonably be considered political.' See Constitutional Convention Bill, http://www.publications.parliament.uk/pa/bills/lbill/2015-2016/0010/16010.pdf

${ }^{6}$ See https://hansard.parliament.uk/Commons/2016-0720/debates/16072031000003/CitizensConventionOnDemocracy

${ }^{7}$ See http://assembliesfordemocracy.org/2015/11/17/convention-on-the-constitution-movesstep-nearer/

${ }^{8}$ One UK design question I bracket is how a convention process operates across regions and nations. One logical possibility is a single authoritative convention for the whole UK. 
Another is a process which builds up from conventions in regions and nations with the results of local conventions taken as guidance or binding for the wider convention. I also do not much discuss questions of duration, publicity and size.

${ }^{9}$ See Renwick 2014, 104-123; also Farrell 2014, Electoral Reform Society 2015, and Blick 2015, 247-257. Caluwaerts and Reuchamps 2016 discuss these powers in their related analysis of 'input legitimacy' and 'output legitimacy'. Farrell 2014 analyses a number of realworld conventions in terms of how they answer such design questions. Table 1 builds on these analyses to indicate all the logical possibilities.

${ }^{10}$ It might be objected that 'citizen' is too restrictive and that 'the people' represented in a CC should include non-citizens. See Owen 2014.

${ }^{11}$ Of course MPs are also citizens, but it is helpful to try to mark the difference in political status between MPs and other citizens.

${ }^{12}$ See Caluwaerts and Reuchamps 2016, 20-21.

${ }^{13}$ The Irish convention was given eight topics to consider by the government. It was free to use any remaining time in its twelve-month duration to consider further issues of its choosing. It identified and considered two.

${ }^{14}$ See note 5 .

${ }^{15}$ The formulation that '[a]t least $50 \%$ of the members of the convention must not be employed in a role which can reasonably be considered political', while consistent with a citizen majority as defined here, is also consistent with a $\mathrm{CC}$ in which a majority of members are drawn from politicians and socially proximate representatives of civil society groups, with members of the general public in a minority. The Australian People's Constitutional Convention lay somewhere between CC4 and CC8. Its agenda and output were largely under Parliamentary control, with its membership half elected and half selected to represent civil society groups; see Tierney 2012, 185-225.

${ }^{16}$ Renwick takes the framework from Jon Elster. See Elster 2012, 150-151. The suggested contrast between impartiality and 'passion' warrants discussion I lack space for here.

${ }^{17}$ These criteria include most of those developed in Renwick 2014, 95-103, but with additional elaboration of the concern for popular sovereignty and explicit addition of a minority tyranny concern (though the majority tyranny concern has some overlap with Renwick's 'public legitimacy' criterion). Renwick's focus on 'political legitimacy' is integrated into the subsequent discussion through discussion of the 'buy in' argument for including politicians in a $\mathrm{CC}$.

${ }^{18}$ Thompson 2008 also explains why we should not give decisions over political structures (e.g., electoral rules) to courts or expert commissions. Commissions are socially too close to politicians and lack accountability; as a matter of democratic legitimacy, courts should not make decisions on what basic political structures ought to be, rather than adjudicate on whether the established rules have been followed. In the UK context, see also Blick 2015, 248-249. 
${ }^{19}$ Near-random selection of members expresses the idea that 'The task of constitutional construction properly belongs to people like me'. It thereby reinforces the sense that constitutional responsibility belongs to us all. A descriptively representative $\mathrm{CC}$ is thereby more consistent with the value of inclusive responsibility than, say, an elected $\mathrm{CC}$ that is not as descriptively representative or one selected mainly from politicians or experts.

${ }^{20}$ Caluwaerts and Reucamps 2016 emphasise the degree of self-selection involved in the British Columbia citizens' assembly and the Dutch Burgerforum.

${ }^{21}$ I thank an anonymous reviewer for raising this point.

${ }^{22}$ For an informative discussion of recruitment challenges in the case of the 'Democracy Matters' pilot assemblies, see Flinders et al 2016, 13-17.

${ }^{23}$ What if the $\mathrm{CC}$ is being asked to function as a full-blown constituent assembly, to construct a draft of a complete constitution? In this case, the problem of focus can be addressed by ensuring that the CC's deliberation starts from an initial draft perhaps drawn up under Parliament's guidance and/or by an independent panel of experts (Blick 2015, 254). Provided that the $\mathrm{CC}$ has ample opportunity to revise the draft, and to draw on a wider public conversation to do this, the $\mathrm{CC}$ can retain significant independence. In the recent 'Democracy Matters' project, Assembly North was presented with the existing proposals for local devolution as a focus for discussion but rejected them in favour of a different model it developed (Flinders et al 2016, 25-35).

${ }^{24}$ Concretely, the Purvis Bill's list of topics for a CC illustrates what I mean by a 'topic' (see note 5). I thank an anonymous reviewer for pointing out the ambiguity in the scope of a 'topic'.

${ }^{25}$ Christopher Zurn argues for a constitutional amendment process requiring that a proposed amendment goes to referendum only if approved by three separate randomly-selected citizens' assemblies.

${ }^{26}$ We certainly have examples of parliaments shelving recommendations from CCs. In the Icelandic case there was a positive non-binding referendum result on questions related to the draft constitution. However, the parliament subsequently ignored the draft constitution. In the recent Irish case, parliamentarians have been criticised for not responding to the convention's recommendations (Farrell 2015).

${ }^{27}$ Tierney 2012, 292-294, also helpfully discusses how to facilitate deliberative quality in referendums.

${ }^{28}$ If the conclusion looks messy, we have in fact only started to reveal how messy things are. One complication, for example, is that we may face a cluster of constitutional issues some of which are best handled by $\mathrm{CC} 1$, but where others, in context, are more reasonably handled by another model. Another complicating consideration is that a given institutional issue can possibly implicate both minority and majority tyranny concerns and so have contradictory CC design implications. 
${ }^{29}$ Where a 'convention' is called on a non-governmental basis, e.g., by Opposition parties, there is no question of making membership akin to jury duty.

${ }^{30}$ Participants in the 'Democracy Matters' assemblies had above average interest in political matters. However, both assemblies achieved good quality deliberation, though Assembly South had some initial deliberative problems. See Flinders et al 2016, 16, 37-41. 